\title{
The representation of Bersih 4.0 and Red Shirt Rallies in a Malaysian newspaper: A comparative analysis
}

\author{
Noor Aqsa Nabila Mat Isa \\ Department of English Language, Faculty of Languages and Linguistics, Universiti Malaya \\ Correspondence: Noor Aqsa Nabila Binti Mat Isa (email: aqsanabila@um.edu.my)
}

Received: 01 October 2020; Accepted: 24 November 2020; Published: 29 November 2020

\begin{abstract}
This study examines the representation of actors and their actions in the news reports by the New Straits Times (NST) about pro-governmental and oppositional rallies in Malaysia, namely the Red Shirt and Bersih 4.0 rallies, respectively in order to find out whether there is a neutral stance in the reporting of these events. To analyse the data, Reisigl and Wodak's (2016) discourse-historical approach (DHA) to critical discourse studies (CDS) has been employed. Specifically, the study looks at how the NST label and describe the actors involved in the reports, as well as their actions during the rallies through nomination and predication strategies as listed in the DHA. Based on the analysis, there is evidence of both groups of actors being depicted as the outgroups. However, the actors involved in the Red Shirt rally have been attributed mostly positively as opposed to their opponents. Interestingly, when the Red Shirt rally-goers were described negatively, this was countered with negative attributes of the Bersih rally-goers who have been described to be worse than them, and this might work to overshadow their own downsides. Based on the findings, it is evident that the NST seem to have constructed their reports in favour of the then-ruling party which was the Barisan Nasional (BN) coalition government.
\end{abstract}

Keywords: Bersih 4.0, critical discourse studies, discourse historical approach, discursive strategies, Red Shirt rally, representation of actors

\section{Introduction}

In 2007, a civic movement in Malaysia named the Coalition of Free and Fair Elections, or better known as Bersih (meaning 'clean' in Malay), held its first rally due to the allegation that the thenuninterrupted ruling by one party since the country's independence in 1957 (i.e. the former Barisan Nasional (BN) coalition) was corrupted due to electoral misconducts. Its demand for a political change continued thereafter, with four massive rallies taking place in 2010, 2012, 2015 and 2016. The focus of this study is on the rally held in 2015 as it was the first time that a protest against Bersih called the Red Shirt rally was conducted, and this provides an interesting premise for a comparative analysis of the news coverage pertaining to these two events. 
The fourth rally called Bersih 4.0 held on $29^{\text {th }}$ August 2015 not only demanded for a clean election, but also the resignation of Malaysia's former Prime Minister Najib Razak due to allegations of a financial scandal linked to a state fund called 1Malaysia Development Berhad (1MDB) that an approximate amount of USD 700 million had been wired to his personal bank accounts (Wright and Clark, 2015). Following this event was the Red Shirt rally (also known as Himpunan Maruah Melayu or Malay Dignity Gathering) that was held two weeks later to counter Bersih 4.0 whereby the participants showed support for Najib Razak and the government. Joined by only the Malays, this rally is said to be "racist" in nature as there were slurs against mainly the Chinese ("Azmin: Malaysia Day became day of shame with 'racist' 'red shirt' rally", 2015) as it was alleged that Bersih rallies were attempts made by the Chinese to challenge the political power of the Malays.

Like any other political rallies, these two rallies have received considerable media attention locally as well as internationally. Focusing on the news reports written by a local newspaper, this study seeks to find out whether there is any bias in the reporting of these events. Theoretically, the purpose of journalism is to provide people with information of events and current issues where conflicting standpoints meet (Talbot, 2007); however, it is often unlikely for the media to be neutral in their write-ups especially if they are within the control of powerful elites (Van Dijk, 1995). According to Widdowson (2000), power can be exercised in texts whereby it allows for implicit ideologies to be constructed to shape public perceptions.

In the Malaysian context, there are more than thirty laws that govern media activities (Iga, 2008). Although Article 10(1) of the Federal Constitution states that each citizen is to be guaranteed the right to freedom of speech, together with the rights to assemble (in peace and without arms) and to form associations, Sani (2005) asserts that Malaysia is not ready for freedom of expression to be fully exercised for fear that it may cause "political instability and inter-ethnic unrest, which would undermine economic development" (p. 345). This explains the formation of Bersih, although it was then decried for demanding political changes involving the thengovernment. Taylor and Kent (1999) highlight on the Malaysian media and the government's relationship whereby during the $\mathrm{BN}$ era, the media were expected to cover pro-government stories, or they would have their licenses terminated if they publicly criticised the government. Sani (2005) adds that the media were put 'under surveillance' by the Malaysian government so that the political leaders could maintain their power and ensure that the ruling party continued to survive. This situation reflects Widdowson's (2000) and Van Dijk's (1995) notion of a more powerful organization having access to the media especially for political benefits.

However, when the BN coalition lost its power for the first time to its opposition coalition Pakatan Harapan (Alliance of Hope) in the $14^{\text {th }}$ General Election in 2018, the journalism world has become "much more relaxed, self-censorship has declined dramatically and the print media are now offering a fuller and more balanced range of viewpoints", as reported by Reporters Without Borders (RSF) ("Malaysia: Fresh air but archaic laws endure", n.d.). Nonetheless, the media still feel intimidated by the previous laws that still exist, and this may hinder them from completely expressing themselves freely.

\section{Literature review}

In regard to past studies that examine Bersih rallies, among the focuses have been on the role of the Internet or the digital media in mobilizing supporters of these rallies (e.g. Kaur, Yee and Lean, 
2011; Lim, 2017; Radue, 2012) and the role of the Bersih movement in the country's democratic processes (e.g. Chong, 2018; Lee, 2014). Very few look at its media representation and how this may work to shape public opinion regarding the movement.

In studies that look at the representation of Bersih in the media, an instance is by Kung (2017) which examines the ways the local mainstream and alternative media (i.e. The Star and Malaysiakini, respectively) frame their news articles and opinion columns in the reporting of the third and fourth Bersih rallies, and the similarities and differences in their framing of these events. His findings reveal that both media were biased in their reporting - The Star was more progovernment, and Malaysiakini the opposite. This is evident in the "us vs. them" dichotomy constructed in both media whereby in The Star, "us" refers to the ruling party, while "them" refers to the Bersih 3.0 and Bersih 4.0 rally-goers. In the meantime, Malaysiakini was reported to construct the opposite.

Another instance is a study by Sanawi (2014) which looks at the visual representations of Bersih 3.0 in three newspapers, namely Utusan Malaysia, The Star and Harakah. He found that Utusan Malaysia attempted to juxtapose the rally with a racial riot that occurred on $13^{\text {th }}$ May 1969 which claimed many lives, depicting the rally-goers as violent and dirty. Meanwhile the Star comprised both positive and negative representations of the rally-goers whereby they were portrayed as being respectful to the authorities first before the rally turned violent through the depiction of participants demolishing a police vehicle. On the other hand, Harakah was shown as being supportive towards the cause as they depicted the rally-goers as being joyful as if they were in a carnival. Harakah highlighted on the unity of the different races in Malaysia in their fight for social justice.

In the meantime, no studies concerning the media representation of the Red Shirt rally have been identified in the literature. Due to the lack of studies done on the representation of both Bersih and the Red Shirt rallies in the media especially from the linguistic perspective, the current study hopes to contribute further to the body of knowledge about these two events. Therefore, the aim of this study is to explore how the news reports about these rallies have been constructed in order to see whether there is a neutral stance in the reporting. Specifically, this study looks at how the actors and their actions in these reports have been discursively constructed by drawing on Reisigl and Wodak's (2016) discourse-historical approach (DHA) to critical discourse studies (CDS) for the analysis. It is hoped that this study could uncover the extent to which the media could shape public opinion on certain issues through the use of language.

\section{Methodology}

This study seeks to explore how Bersih 4.0 and Red Shirt rallies were represented by one of the oldest Malaysian newspapers, The New Straits Times (NST). On its website, five articles written for each rally since the first day of these events were selected randomly to provide insights into the different ways that the rallies have been talked about. Among the articles that were not taken into consideration are those that mention the rallies rather briefly (e.g. issues on buses that were not authorized to carry rally-goers), as well as opinion pieces that reflect specific authors' take on the issues covered. Below are the headlines of the reports selected for this study.

Bersih 4.0:

1. PM: Demonstrators have no love for the country 
2. Bersih organisers don't care about people's welfare

3. Bersih observers' attempt to force reporters to leave leads to heated argument

4. Nur Jazlan thankful for peaceful rally

5. Bersih 4: 27 police reports lodged

Red Shirt rally:

1. Red Shirt rally: Water cannon deployed against protesters

2. Red Shirt rally: All quiet at Petaling Street

3. Those who incited hatred during Red Shirt rally to be [charged] under Sedition Act: PM

4. Red Shirt rally: No 'bad smell of urine', just rubbish: Rahman Dahlan

5. Red Shirt rally: Pekida joins rally

\section{Analytical Framework in Use}

Since this study analyses the language use in news reports about pro-governmental and oppositional rallies, the exploration of the relations between language, power and ideology in the media discourse has been the central focus and this is explained from a critical discursive perspective or CDS. According to Fairclough and Wodak (1997), language is viewed as a form of social practice. Social theories are incorporated in the analysis of textual elements to explain in detail how and why a particular discourse is produced in order to demystify ideologies and power in the discourse (Wodak, 2013). Briefly, CDS allows for the analysis of "opaque as well as transparent structural relationships of dominance, discrimination, power and control as manifested in language" (Wodak and Meyer, 2001, p. 2). In other words, it works to uncover "manipulation in texts" (van Dijk, 1995, p. 19) and "social inequality" (Wodak and Meyer, 2001, p. 2) that are constructed to serve the interest of the text producers or more powerful agents. For instance, Dağtaş (2013) states that those in power such as political leaders (e.g. minister or president of a country) are more likely to be given opportunity to have a say than the powerless. In her study on the reporting of "Arab Spring" in Turkish national newspapers, direct quotations from leaders and foreign ministers are most commonly used, whereas the voice of the protesters have been suppressed.

For this study, Reisigl and Wodak's (2016) discourse-historical approach (DHA) to CDS has been employed to analyse the content of the selected newspaper articles. Out of the many analytical tools in the DHA for analysis, they have given special attention to five discursive strategies. These strategies can explain how the actors and their actions are positively or negatively labeled (through nomination and predication strategies), why they are atrributed in such ways (through argumentation strategies), from which point of view they are expressed (through perspectivization strategies), and finally in what manner they are represented (through intensification and mitigation strategies). However, the focus of the analysis is only on the nomination and predication strategies as these are the strategies that seem to be the most saliently used in the data which can best describe the social actors and actions involved.

\section{Results and discussion}

The representation of actors and their actions in the news reports of Bersih 4.0

According to Reisigl and Wodak (2016), the discrimination of actors and their actions in a text can 
be observed from the ways they are represented. The social actors reported in the news articles about Bersih 4.0 and the Red Shirt rally are classified into two main groups: the anti-establishment (i.e. those who organised, joined and supported Bersih 4.0) as well as pro-establishment (i.e. those on the government's side) actors. Table 1 below shows instances of the nomination and predication strategies that are used to talk about both groups of actors and their actions in the news reports about Bersih 4.0.

Table 1. : Nomination and predication strategies in the news reports about Bersih 4.0

\begin{tabular}{|c|c|c|}
\hline Discursive strategies & Anti-establishment & Pro-establishment \\
\hline Nomination strategies: & Discursive constru & ion of social actors: \\
\hline \multirow[t]{5}{*}{$\begin{array}{l}\text { How are persons, objects, } \\
\text { phenomena, events, } \\
\text { processes and actions } \\
\text { related to the news reports } \\
\text { about Bersih } 4.0 \text { named } \\
\text { and referred to } \\
\text { linguistically? }\end{array}$} & $\begin{array}{l}\text { Those involved in the anti- } \\
\text { establishment demonstration, } \\
\text { demonstrators, they, 21-year-old } \\
\text { man, organisers of the Bersih } 4.0 \\
\text { rally, few, they, them, their, } 20,000 \\
\text { people, Bersih observers, human } \\
\text { chain, Bersih } 4 \text { participants, } \\
\text { "anarchists", rally-goers }\end{array}$ & $\begin{array}{l}\text { Prime Minister Datuk Seri Najib } \\
\text { Razak, Umno president, we, he, } \\
\text { police, public, majority of } \\
\text { Malaysians not at the rally, Felda, } \\
\text { Bersih } 4 \text { rally security observers, } \\
\text { several police officers, Deputy } \\
\text { Superintendent Gurbinder Singh, } \\
\text { Deputy Home Minister Datuk Nur } \\
\text { Jazlan Mohamad, the government }\end{array}$ \\
\hline & \multicolumn{2}{|c|}{ Discursive construction of objects/phenomena/events: } \\
\hline & $\begin{array}{l}\text { Bersih 4, } 27 \text { police reports, rally, } \\
\text { argument, Dataran Merdeka }\end{array}$ & $\begin{array}{l}\text { Malaysia, other countries, Merdeka } \\
\text { day, Merdeka month, Bukit Jalil, } \\
\text { Merdeka parade }\end{array}$ \\
\hline & \multicolumn{2}{|c|}{ Discursive construction of processes and actions: } \\
\hline & $\begin{array}{l}\text { Humiliate Malaysia to other } \\
\text { countries, should instead fly the } \\
\text { national flag (Merdeka month), } \\
\text { disturb the harmony and tarnish } \\
\text { the image of Malaysia, arrested, } \\
\text { investigated, failing to produce } \\
\text { identification when asked by the } \\
\text { police, do not care (about people's } \\
\text { welfare and about developing rural } \\
\text { areas), complaining about } \\
\text { problems and financial crisis, will } \\
\text { never end, tried to shoo away } \\
\text { media members, forming human } \\
\text { chain by holding hands together in } \\
\text { a line, marching away in an } \\
\text { attempt to force reporters to leave, } \\
\text { (reporters) not let through and } \\
\text { were instead ordered to leave, } \\
\text { would provoke the police into } \\
\text { using force against them, taking it } \\
\text { to the streets, should channel } \\
\text { dissatisfaction towards the } \\
\text { government via a ballot box }\end{array}$ & $\begin{array}{l}\text { Continue to ensure that the } \\
\text { situation is under control, (safety } \\
\text { is) assured, attending the Merdeka } \\
\text { parade, supported the government, } \\
\text { can easily rally } 100,000 \text { settlers, } \\
\text { had to intervene before the tense } \\
\text { situation was diffused, thanked } \\
\text { Bersih } 4 \text { participants and the police } \\
\text { on duty, maintaining public order, } \\
\text { urged the public to stay away from } \\
\text { Bersih } 4 \text { rally, without naming the } \\
\text { planned Bersih } 4.0 \text { rally (in Najib } \\
\text { Razak's speech) }\end{array}$ \\
\hline Predication strategies: & \multicolumn{2}{|c|}{$\begin{array}{l}\text { Discursive characterization/qualification of social actors (positively } \\
\text { or negatively): }\end{array}$} \\
\hline $\begin{array}{l}\text { qualities and features are } \\
\text { attributed to social actors, }\end{array}$ & $\begin{array}{l}\text { Devoid of love for the country, too } \\
\text { shallow, no love for the country, } \\
\text { disgruntled (few) }\end{array}$ & $\begin{array}{l}\text { (Public should not be) alarmed, } \\
\text { grateful (with the government), }\end{array}$ \\
\hline
\end{tabular}




\begin{tabular}{lcc}
\hline Discursive strategies & Anti-establishment & \multicolumn{1}{c}{ Pro-establishment } \\
\hline $\begin{array}{l}\text { objects, phenomena/ } \\
\text { events and processes? }\end{array}$ & $\begin{array}{l}\text { patients and tolerant (police), } \\
\text { thankful }\end{array}$ \\
\cline { 2 - 3 } & $\begin{array}{r}\text { Discursive characterization/qualification of objects, phenomena, } \\
\text { events, processes and actions (positively or negatively): }\end{array}$ \\
\cline { 2 - 3 } & Heated (argument), peaceful (rally) & Under control \\
\hline
\end{tabular}

Based on Table 1, the nomination strategies that the NST used to talk about the antiestablishment actors show the use of pronouns and names such as 'they', 'them', 'their', 'demonstrators', 'Bersih organisers' and 'Bersih 4 participants'. Here, they seem to be collectively referred to as an outgroup when they were further described mostly negatively as 'disgruntled few' that showed 'no love for the country' and were 'too shallow'. Since Bersih 4.0 was conducted close to Merdeka Day (the Malaysian Independence Day) celebration and within the vicinity of the historical place, Dataran Merdeka (Independence Square) where the Malayan flag was hoisted on August 31, 1957 for the first time indicating the country's independence from Britain, the rallygoers have been described as those who did not respect the historical day and venue. They were delegitimized as a group of people that would give the country a bad image (e.g. 'humiliate Malaysia to other countries').

Furthermore, the Bersih organisers were also depicted as being negligent of other more important issue that should be given more attention to, in this case, the welfare of the poor in the rural areas, which was brought up in a speech by Najib Razak at the Felda Settlers Day celebration on the day of the rally. Another interesting example to look at is the word 'shoo' that was used to describe the action of the Bersih security observers on the media members. 'Shoo' is defined as a word that is "said to animals or children to make them go away" ("Shoo," n.d.). Here, the media members covering the event were positioned to be treated like "animals" or "children" that caused problems to the rally-goers. The only positive label associated with the rally is 'peaceful' which was quoted in the then-Deputy Home Minister Datuk Nur Jazlan Mohamad's speech, describing the first day of Bersih 4.0. Prior to the rally, he was reported to have warned the public of the possible presence of 'anarchists' who would 'provoke the police into using force against them'.

In the meantime, there were also references to the pro-establishment actors such as 'we' that refers to the Malaysians as a whole (excluding the rally-goers), 'the majority of Malaysians who were not at the rally' who were positioned as the government supporters, and 'Felda' which is a government's agency. In contrast with the anti-establishment actors, they were labelled and described positively (e.g. 'supported the government' by not attending the Bersih rally, and feeling 'grateful' for the then-government). Interestingly, in one of the reports, Najib Razak has been given a positive evaluation in the linguistic form of implicit predicate "Without naming the planned Bersih 4.0 rally...". This avoidance of membership categorisation (of the rally-goers) in his speech, which could also be viewed as the suppression strategy put forward by van Leeuwen (2008), suggests a positive representation of Najib Razak as the then-PM, in which the text producer might not want him to be seen pointing his finger directly to the intended opponent. This may position him positively as a leader that was cautious with his word choices.

\section{The representation of actors and their actions in the news reports of the Red Shirt rally}

The following Table 2 shows instances of the nomination and predication strategies that are used to talk about both groups of actors and their actions in the news reports about the Red Shirt rally. 
Table 2. : Nomination and predication strategies in news reports about the Red Shirt rally

\section{Discursive strategies Nomination strategies:}

How are persons, objects, phenomena, events, processes and actions related to the news reports about the Red Shirt rally named and referred to linguistically?

\section{Anti-establishment} Discursive construction of social actors:

Saboteurs, those (involved in the disturbance)
Police, red shirt protesters, they, those, The Federal Reserve Unit (FRU), Federal Territories participants, Federal Territories Umno chief Mohd Razlan Rafii, Perkasa President Tan Sri Mohd Ali Rustam, Himpunan Rakyat Bersatu, Sungai Besar Umno Division Chief Datuk Jamal Yunos, Tan Sri Annuar Musa, Umno Information chief Datuk Ahmad Maslan, Pas Youth chief Nik Mohamad Abduh Nik Abdul Aziz, Kinabatangan member of parliament Datuk Bung Mokhtar Radin, rally-goers, demonstrators of the "Red Shirt" rally, members of Pekida Malaysia, Malay community, a convoy of 300 bikers, government, Housing and Local Government Minister Datuk Abdul Rahman Dahlan, Alam Flora, Red Demo organisers
Discursive construction of objects/phenomena/events:

Disturbance, arrests, Bersih 4 rally, Petaling Street, Padang Merbok, clean-up cost (RM64,955) peace, Kota Raya, Kuala Lumpur, peace, Perak, organisers, (no) sign of tension, shops, Police trucks and buses, the Sedition Act, water cannons, and Kuala Lumpur City Hall (DBKL, just rubbish, cost of clean up (RM38,000)

\section{Discursive construction of processes and actions:}

Paid to provoke both police and Hurled stones and bottles, hitting participants, create chaos, wanted to topple the government
Hurled stones and bottles, hittin
several policemen, reacting to maintain peace, investigate, do not want to incite any chaos, defending the parliamentary democracy, numbers swelled (from just 500), demanding to be allowed to march, carrying the Jalur Gemilang and placards written "Menolak campur tangan asing" (Reject foreign intervention) and "Pertahankan Hak Melayu" (Defend Malay rights), clad in red, blowing airhorns, marched, achieve ultimate goal of Vision 2020 to make Malaysia a fully-developed nation, gathered, not compromise on safety and those who threaten sensitivities of other 


\begin{tabular}{|c|c|c|}
\hline Discursive strategies & Anti-establishment & Pro-establishment \\
\hline & & $\begin{array}{l}\text { races, investigate, inciting racial } \\
\text { hatred charge, encroached (into } \\
\text { restricted areas), disperse, given } \\
\text { green light, did not have any } \\
\text { intention to topple the government, } \\
\text { had no preparations for any event at } \\
\text { the venue, granted a permit, did not } \\
\text { leave (bad smell of urine) }\end{array}$ \\
\hline Predication strategies: & \multicolumn{2}{|c|}{ 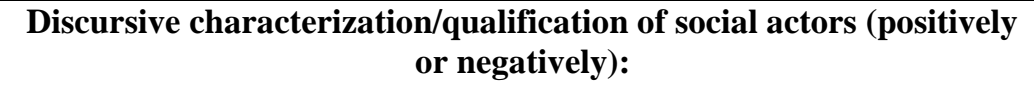 } \\
\hline \multirow{3}{*}{$\begin{array}{l}\text { What characteristics, } \\
\text { qualities and features are } \\
\text { attributed to social actors, } \\
\text { objects, phenomena/ } \\
\text { events and processes? }\end{array}$} & Illegal (Bersih 4 organisers) & $\begin{array}{l}\text { Unruly, irritated, baik (good - } \\
\text { police), relevant (authorities) }\end{array}$ \\
\hline & \multicolumn{2}{|c|}{$\begin{array}{l}\text { Discursive characterization/qualification of objects, phenomena, } \\
\text { events, processes and actions (positively or negatively): }\end{array}$} \\
\hline & Bad (smell of urine) & $\begin{array}{l}\text { Legal, restricted, off-limits (three } \\
\text { areas), right (cause), peaceful, } \\
\text { calm, heavy (police presence), } \\
\text { important (for people to voice out } \\
\text { opinions), not evident (smell of } \\
\text { urine), quiet }\end{array}$ \\
\hline
\end{tabular}

Here, there are more positive attributes assigned to the pro-establishment actors, whereas their opposition has been described only negatively. Similar to the earlier findings, the Red Shirt rally-goers seem to be referred to collectively as an out-group, not only through the use of pronouns such as 'they' and 'those', but also when they were depicted as having negative qualities such as 'unruly' and 'irritated'. Additionally, their actions indicate the use of violence such as '[hurling] stones and bottles, hitting several policemen'. Also worth noting is that the rally had strong racial overtones in which the then-government has been described as condemning it and having no tolerance for any of the racist rally-goers. These labels and descriptions may seem to indicate the NST's way of being neutral in the reporting of this event, just as how they reported Bersih 4.0; however, further analyses have proved otherwise.

In the news reports about the Red Shirt rally, there are many instances in which the government political leaders have been named and quoted (as opposed to the news reports about Bersih 4.0), mainly to show their support and involvement in the rally, as well as to back up the event and the rally-goers when they were associated with unfavourable acts. To illustrate, in one of the news reports, although the Red Shirt rally-goers were said to be causing chaos at the beginning of the event (i.e. being present in off-limit areas such as Petaling Street), a few authorities were then quoted later, stating that they believed it was an act of sabotage. This can be seen as an attempt to disassociate the rally-goers from negative attributes. In another report, the rally-goers were then described as duly complying with the police order when asked to leave later, and that the venue was 'quiet' with 'no sign of tension', suggesting peace and calmness.

There are also interesting instances demonstrating that when the Red Shirt rally-goers were further evaluated negatively, there is evidence of comparisons being made to that of the Bersih rally-goers who were often described to be worse than them. An example is when the Red Shirt rally-goers were described as being unhygienic (by 'just (throwing) rubbish'), the Bersih rallygoers were not only said to be littering, but also leaving urine odour behind. This implies that the negative evaluation of the pro-establishment actors has been downplayed by highlighting on the 
flaws of the opponent. Similar strategy of comparisons can be seen concerning the clean-up costs billed to the organisers (RM38,000 for the Red Shirt, and RM64,955 for Bersih), and the legality and demands of both rallies. The Red Shirt rally was described as 'legal' and therefore 'given green light' and 'granted a permit' by authorities for intending to defend the then-government, and Bersih as 'illegal' for wanting to oust it.

To sum up briefly, the findings concur with Widdowson's (2000) and van Dijk's (1995) notion in that more powerful agents often have control over the media to assist them in spreading their ideologies, in which in the case of the present study, to delegitimize and demonize the act of the anti-establishment actors who were said to have wanted to topple down the then-government. This demonstrates the government's effort to circumscribe Bersih's freedom of expression as the rally advocated political changes against it.

\section{Conclusion}

This study examines the representation of Bersih 4.0 and the Red Shirt rally by the NST in terms of how the actors involved in the selected texts and their actions have been talked about to see whether there is a neutral stance. Based on the analyses, it is evident that the authors of the articles seem to be in favour of the ruling party which was the then-BN coalition government. Based on the findings, the anti-establishment actors have been portrayed mostly negatively, while such is not the case for the pro-establishment actors. For instance, the Bersih 4.0 rally-goers' actions have been described as impacting the country negatively (e.g. 'tarnish the image of Malaysia' and 'humiliate Malaysia to other countries'). This may influence readers to have negative views of the Bersih rally. As for the pro-establishment actors, apart from the many positive attributes associated with them, there are also instances of them being reported negatively (though minimally). However, this was countered with negative attributes of their opponents which might work to overshadow their own downsides.

As a final remark, it is hoped that this study has provided an insight into the different ways that news reports can be constructed to influence readers' opinions on the issues being reported. Biasness in news reporting is not new; therefore, readers must be aware of a text producer's stance on an issue and keep themselves well informed by cross checking information that they obtain with other sources.

\section{References}

Azmin: Malaysia Day became day of shame with 'racist' 'red shirt' rally (2010, September 17 September), Malay Mail. Retrieved from https://www.malaymail.com/news/malaysia/2015/09/17/azmin-malaysia-day-becameday-of-shame-with-racist-red-shirt-rally/971511

Chong, C. T. (2018). Democratic breakthrough in Malaysia-Political opportunities and the role of Bersih. Journal of Current Southeast Asian Affairs, 37(3), 109-137. https://doi.org/10.1177/186810341803700306

Dağtaş, B. (2013). Constructing the "Arab Spring": News Discourses in Turkish Newspapers. Global Media Journal: Canadian Edition. 6(2), 19-33.

Fairclough, N. and Wodak, R. (1997). Critical Discourse Analysis, in T. A. van Dijk, Discourse 
as Social Interaction (pp. 258-284). London: Sage.

Iga, T. (2008). The role of media and media freedom in democratizing countries: A comparative study of Indonesian and Malaysian Media, presented at Conference on Confluences and challenges in building the Asian community in the early 21 century. API publications.

Kaur, S., Yee, Y.M.T., \& Lean, M.L. (2011). Social networking and Bersih 2.0 rally in Malaysia. Asian Conflicts Reports, 19(Sept-Nov). Retrieved from https://umexpert.um.edu.my/public_view.php?type=publication\&row=ODM3NDE\%3D

Kung, K. J. (2017). News Framing: A Comparative Study of Bersih 3.0 and Bersih 4.0 in the Star and Malaysiakini's News Articles and Opinion Columns (master 's thesis). UTAR.

Lee, J. C. (2014). Multiculturalism and Malaysia's (Semi-) Democracy: Movements for Electoral Reform in an Evolving Ethno-Political Landscape. In Multicultural challenges and sustainable democracy in Europe and East Asia (pp. 83-105). Palgrave Macmillan, London.

Lim, M. (2017). Digital media and Malaysia's electoral reform movement. In Citizenship and democratization in Southeast Asia (pp. 209-237). Leiden,Brill.

Malaysia : Fresh air but archaic laws endure. (n.d.). Reporters without borders. Retrieved from https://rsf.org/en/malaysia

Radue, M. (2012). The Internet' ${ }^{\prime}$ s role in the Bersih movement in Malaysia-A Case Study. The International Review of Information Ethics, 18, 60-70.

Reisigl, M. and Wodak, R. (2016). The discourse-historical approach. In R. Wodak and M. Meyer (Eds.), Methods of critical discourse studies (pp. 23-61). London, Sage.

Sanawi, J. B. (2014). Ideologies underlying the use of photographs in newspaper coverage of Bersih 3.0 rally: A social semiotic analysis. Jurnal Komunikasi: Malaysian Journal of Communication, 30 (2). 41-60. https://doi.org/10.17576/JKMJC-2014-3002-03

Shoo. (n.d.). In Cambridge dictionary. Retrieved from https://dictionary.cambridge.org/ dictionary/english/shoo

Sani, M. A. M. (2005). Media freedom in Malaysia. Journal of Contemporary Asia, 35(3), 341367. https://doi.org/10.1080/00472330580000201

Talbot, M. (2007). Media Discourse: Representation and Interaction. UK, Edinburgh University Press.

Taylor, M., \& Kent, M. L. (1999). Challenging assumptions of international public relations: When government is the most important public. Public Relations Review, 25(2), 131-144.

van Dijk, T. (1995). Aims of critical discourse analysis. Japanese Discourse 1(1), 17-27.

van Leeuwen, T. (2008). Discourse and Practice: New Tools for Discourse Analysis. Oxford: Oxford University Press.

Widdowson, H. (2000) 'Critical practices: On representation and the interpretation of text', In S. Sarangi \& M. Coulthard (eds). Discourse and Social Life, pp. 155-69. London: Pearson Education.

Wodak, R. (Ed.) (2013). Critical Discourse Analysis. London: Sage.

Wodak, R. \& M. Meyer. (2001). Methods of Critical Discourse Analysis. London: Sage.

Wright, T. \& Clark, S. (2015, July 2). Investigators believe money flowed to Malaysian Leader Najib's accounts amid 1MDB probe. The Wall Street Journal. Retrieved from http://www.wsj.com/articles/SB10130211234592774869404581083700187014570 